\title{
Brachydactyly-preaxial hallux varus syndrome
}

INSERM

\section{Source}

INSERM. (1999). Orphanet: an online rare disease and orphan drug data base.

Brachydactyly-preaxial hallux varus syndrome. ORPHA:1278

Preaxial brachydactyly-hallux varus syndrome is characterized the association of hallux varus with short thumbs and first toes (involving the metacarpals, metatarsals, and distal phalanges; the proximal and middle phalanges are of normal length) and abduction of the affected digits. 